Article title: Measuring the Quality of Student Support Services in Open Distance E-Learning

Authors: Tsige GebreMeskel Aberra[1]

Affiliations: University of South Africa, College of Graduate Studies, Ethiopia Regional Learning Centre, Ethopia[1]

Orcid ids: 0000-0003-4798-0096[1]

Contact e-mail: abertg@unisa.ac.za

License information: This work has been published open access under Creative Commons Attribution License http://creativecommons.org/licenses/by/4.0/, which permits unrestricted use, distribution, and reproduction in any medium, provided the original work is properly cited. Conditions, terms of use and publishing policy can be found at https://www.scienceopen.com/.

Preprint statement: This article is a preprint and has not been peer-reviewed, under consideration and submitted to UnisaRxiv for open peer review.

DOI: 10.25159/UnisaRxiv/000002.v1

Preprint first posted online: 03 December 2020

Keywords: content validity, student support, service quality, ODeL, Ethiopia 


\title{
Measuring the Quality of Student Support Services in Open Distance E-Learning
}

\author{
Tsige GebreMeskel Aberra \\ https://orcid.org/0000-0003-4798-0096 \\ University of South Africa \\ abertg@unisa.ac.za
}

\begin{abstract}
Student support services are essential elements in the success of open distance e-learning. These services help students to become competent in achieving their goals. However, the level of the quality of services should be measured so that continuous improvements can be made, which in turn bring about sustainability of positive results. This article takes content validity as its focus in the development of an instrument that allows for measuring student support services in open distance e-learning. By exposing the instrument to 10 experts, items were refined in the form of deletions, additions, and splitting of double-barrelled items. Experts' ratings were analysed through the content validity index for each item, each dimension and the overall instrument. The content validity processes undertaken in this article have resulted in getting a 50-item 5-dimensional instrument. This article reveals that the use of content validity procedures is one of the most recommended methods in securing the validity of an instrument in terms of its involving appropriate items and dimensions.
\end{abstract}

Keywords: content validity, student support, service quality, ODeL, Ethiopia

\section{Introduction}

The efficiency and effectiveness of open distance e-learning (ODeL) programmes depend on the individualised student support services on offer. Student support services in ODeL help to decrease dropout rates and increase the success of the programmes. Moreover, students can be retained in the system and more throughput rates can be achieved. It is through student support services that learners are linked to the educational institution (Southard and Mooney 2015, 56). Student support services boost ODeL students' confidence and make them more competent in the world of work. These call for the offered student support services to be of the right quality (Dzakiria 2005, 106).

The openness of ODeL allows flexibility by making learners choose what to learn and when to learn it. ODeL uses the technology of the time in maximising accessibility of education to learners by bringing knowledge to their respective locations (Tait $2014,15)$. These characteristics call for the right means of assessing quality in the ODeL system (Stella and Gnanam as quoted in Jung et al. 2011, 64). 
An organisation can be competitive when its products or services are of the right quality. This leads to the satisfaction of its customers, who are doctoral students in the case of this study. Being an elusive construct, however, the first step in understanding and improving quality is measuring it (Jain, Sinha, and De 2010, 144). Measuring service quality in turn depends on the context in which the goods and services are offered and the types of industry such as education or tourism (Teeroovengadum, Kamalanabhan, and Seebaluck 2016, 246).

The concept of quality demands continued improvement of goods and services on offer, which in turn is best done through customers' evaluation. In higher education, students, as primary customers, should evaluate the services to identify the points that need intervention by the educational institution. Apart from getting customers' views, it is important to compare the offerings with institutions that are in similar business in order to determine the competitiveness of the firm (Maguad and Krone 2012,27).

The fact that quality is a multi-dimensional construct calls for the development of an instrument that includes essential dimensions which truly reflect the subject of investigation; in the case of this study, the quality of student support services in ODeL (Sultan and Wong 2010,262). The other nature of quality is its being context-bound. This calls for developing an instrument that fits the nature of business under investigation, in the case of this article, higher education. Moreover, the fact that it is ODeL and not the conventional mode of education is another factor that influences the context. The socio-economic condition of the respondents also contributes to defining the context (Jain, Sinha, and De 2010, 145; Malhotra et al. 2005, 259).

The intention of this study is therefore to come up with a suitable instrument that can measure the quality of doctoral student support services with particular reference to the ODeL environment. One of the most contributing factors to come up with a valid and reliable instrument is ascertaining its content validity. Essentially, content validity is one of the many methods that increase the trustworthiness of an instrument (Newman, Lim, and Pineda 2013, 244). It is defined as "the ability of an instrument to measure the properties of the construct under study" (Zamanzadeh et al. 2015, 165). It is the first step in the validation process of an instrument and helps to secure the appropriate content in the effort of developing a measure for a certain construct. The process of content validity assures the operational definitions of the instrument with respect to its items, dimensions and the overall content (Shrotryia and Dhanda 2019, 2-3). Generally, content validity presupposes having adequate number of items in an instrument that are able to fully measure relevant aspects of the construct (Field 2009, 12).

In this article, content validity is conceptualised from the point of view of nursing science, in which case the items in an instrument are subjected to a small number of persons in the field. This is done for the purpose of evaluating each item's clarity and relevance to discard less relevant and less clear items, to identify and correct doublebarrelled items, and to include useful items that best measure the construct under study 
(Magasi et al. 2012, 743). The process of content validity further guarantees to secure the dimensionality (the factor in which each item falls) and the comprehensiveness of an instrument (Rubio et al. 2003, 94).

In the process of securing the content validity of an instrument, authors in the field recommend that items be exposed to experts (Kassam-Adams et al. 2015, 3). The pool of experts can be formed from persons who are researchers and have good knowledge of the field under study. The contribution of this group of persons is evaluating the relevance, clarity and dimensionality of items, and the comprehensiveness of an instrument. Potential respondents of the instrument can be part of the expert pool to identify if there are omitted items in the instrument, and to refine the dimensions (Vogt, King, and King 2004, 233). Persons in the field of testing and measurement can form another pool of experts. This group can make a good contribution in terms of identifying the appropriateness of the structure of the instrument, if there are double-barrelled items, and recommending the statistical tools that should be used after data collection (Grant and Davis 1997, 270; Lampley 2001, 10). The number of persons involved to evaluate an instrument may vary from one study to another with the recommendation of 5 to 10 persons to secure control over chance agreement among them (Zamanzadeh et al. 2015, 168).

Against this background, this article focuses on the use and importance of content validity in the development and refinement of a context-sensitive instrument that is sound enough to measure doctoral student support service quality in the ODeL environment.

\section{Relevant Empirical Studies on Content Validity}

Nguyen, Douglas and Bonner (2019) used a content validity index (CVI) in the process of checking the validity of an English-to-Vietnamese translated instrument that measures self-management behaviour of "chronic kidney disease" patients in Vietnam. They used 10 experts in the field and used a four-point scale so that the experts check the relevance, clarity, and appropriateness of each item. The comprehensiveness of the instrument was also assessed by a two-point scale: "should be deleted" and "should be retained". A space was provided next to each item for comments. After calculating the item-content validity index (I-CVI) for each item and the scale-content validity index (S-CVI) for the whole instrument, they developed a 32-item four dimensional instrument for further evaluation by other validation techniques such as factor analysis.

Zamanzadeh et al. (2015) used 15 experts in the development process of a patientcentred communication instrument that measures the communication between cancer patients and nurses. In the effort of developing a valid instrument, experts were requested to rate the relevance, clarity, and comprehensiveness of an instrument that had 57 items. After using the I-CVI for each item and the S-CVI for the comprehensiveness of the whole instrument, the authors developed a 53-item seven 
dimensional instrument. In the process, experts' comments were used to modify items that needed improvement.

In the process of validating a 22 -item four dimensional instrument that measures stress levels of nursing students in China, Guo et al. (2019) used various methods of which content validity was one. The authors exposed the items to a panel of six experts in the field of nursing (head nurses, nursing professors and clinical practitioners) asking them to rate the relevance of each item on a scale of 1 to 4 . Inter-rater agreement (IRA) was employed to calculate the responses to the six experts and the result was found to have I-CVI values in the range of $0.83-1.0$.

Witte, Labeau, and Keyzer (2011) employed the content validity procedure on the Clinical Learning Environment and Supervision Scale after translating it into Dutch. This instrument is designed to measure nursing students' experiences when they are placed in different clinics. To contextualise the original instrument to the Flemish culture, five items were added by the authors. The translated and modified instrument was then subjected to 12 experts for clarity, relevance and readability. The authors also used other statistical methods (for example, factor analysis) in refining the instrument. The results proved that all the experts agreed on the 32-item five-dimensional instrument having relevant, clear and readable items.

Shrotryia and Dhanda (2019) employed content validity to refine an instrument which they developed to assess the construct of employee engagement. The authors developed the instrument by doing an exploratory study on Human Resource heads of 15 companies, which helped them to come up with 30-item three-dimensional instrument. For the content validity study, they exposed the instrument to six experts, who were pulled from academics and practitioners to evaluate the items and the right alignment of the three dimensions of the instrument. Two items were rated as "not necessary" and hence the instrument passed towards further statistical procedures with 28 items and three dimensions.

\section{Methods and Procedures}

The article focuses on the content validity procedures that were followed in developing an instrument that measures the quality of student support services. Before this procedure, the instrument development process passed through two steps. Step one was development of items with possible dimensions from the literature and students' repeated complaints, which were recorded in the form of reports. During step two, the items were assessed by two raters or judges who evaluated each item along the dimension in which it should fall. The kappa statistic for inter-rater reliability was run and a kappa value of 0.66 was secured (Aberra 2016, 113). In the content validity process, the items and their dimensions were exposed to 10 experts. The experts were drawn from doctoral students (who were potential respondents), professors of the Addis Ababa University in the fields of Marketing and Educational Measurement, and an alumnus, as shown in Table 1 . 
Table 1: Distribution of pool of experts

\begin{tabular}{|c|c|c|}
\hline Pool & Specialisation & Total \\
\hline \multirow{3}{*}{ Students } & Marketing $=3$ & \multirow[t]{3}{*}{6} \\
\hline & Measurement $=2$ & \\
\hline & Governance $=1$ & \\
\hline \multirow{3}{*}{$\begin{array}{l}\text { Staff members of Addis Ababa } \\
\text { University }\end{array}$} & Marketing $=1$ & \multirow[t]{3}{*}{3} \\
\hline & Measurement $=1$ & \\
\hline & Management Science $=1$ & \\
\hline Alumnus & Education & 1 \\
\hline \multicolumn{2}{|l|}{ Total number of experts } & 10 \\
\hline
\end{tabular}

After obtaining the experts' consent to evaluate the items and the full instrument, the abstract of this article was sent to them by email. On the meeting date, a presentation was made on the purpose of this article and on the procedures of the evaluation process. The experts were asked to assess each item for relevance and clarity. They were also asked to evaluate if each item belongs to the dimension it was originally placed and if the overall instrument is comprehensive enough in terms of measuring the quality of student support services in the ODeL context. The contextual meaning of each dimension was stated for ease of reference by the experts (Aberra 2016, 107).

The instrument that consisted of four columns with the headings of evaluating relevance, clarity, and dimension for each item was distributed to the experts. On the right end of the table, a space was provided against each item so that the experts can give comments whenever they find it applicable (Table 2). The measuring scales were adopted from Rubio et al. $(2003,96)$ and Polit, Beck, and Owen $(2007,460)$. After the evaluation session, discussions took place about each of the comments that were made by the experts.

Table 2: Rating scale as used by content experts

\begin{tabular}{|l|l|l|l|l|l|l|l|l|l|l|l|l|}
\hline No & $\begin{array}{l}\text { Items and } \\
\text { dimensions with } \\
\text { their meanings }\end{array}$ & $\begin{array}{l}\text { Item } \\
\text { Relevance/ } \\
\text { importance }\end{array}$ & \multicolumn{2}{|l|}{$\begin{array}{l}\text { Item } \\
\text { Clarity }\end{array}$} & \multicolumn{2}{|l|}{$\begin{array}{l}\text { Dimension } \\
\text { Items 1-10 } \\
\text { fall under } \\
\text { supervision } \\
\text { support }\end{array}$} & $\begin{array}{l}\text { Recommendation } \\
\text { for improvement }\end{array}$ \\
\hline & $\begin{array}{l}\text { Supervision } \\
\text { support: issues } \\
\text { that are directly } \\
\text { linked to the } \\
\text { academic } \\
\text { activities of the } \\
\text { students in } \\
\text { relation to the } \\
\text { instructions or } \\
\text { guidance rendered } \\
\text { by supervisors }\end{array}$ \\
\hline
\end{tabular}




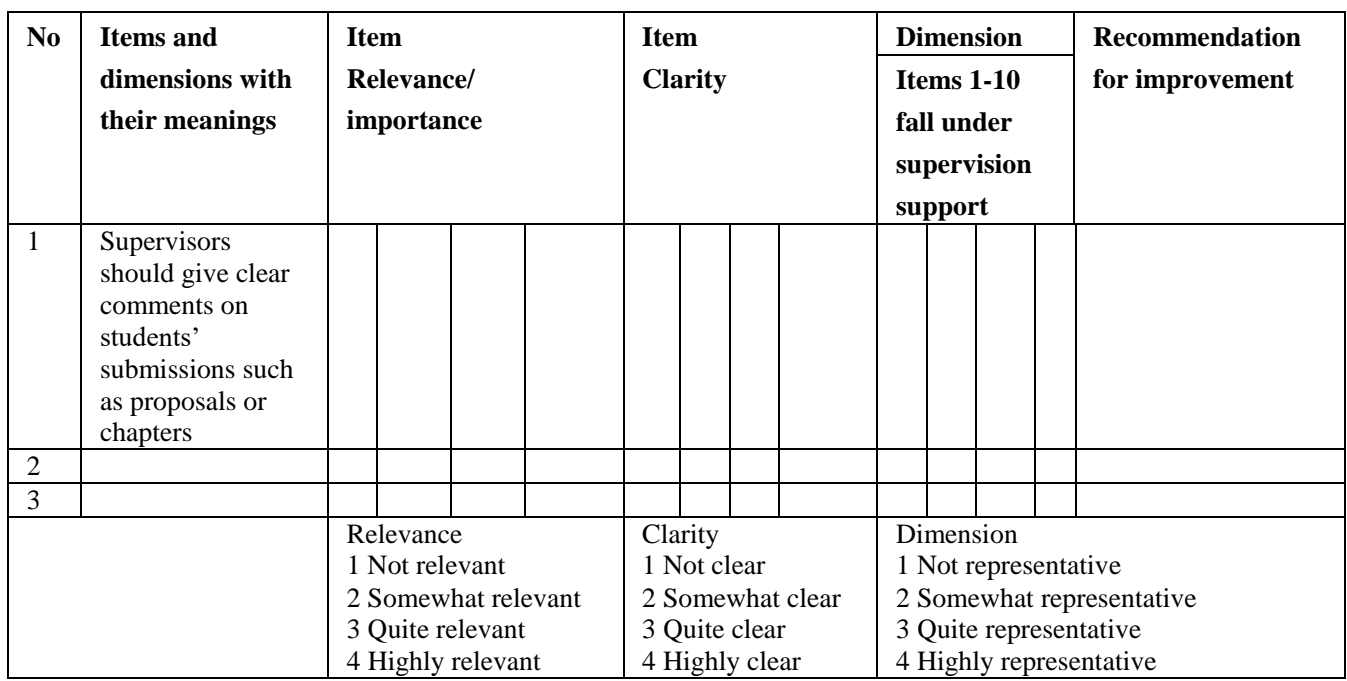

The responses that were collected from the experts were analysed both quantitatively and qualitatively. The IRA is one of the most common methods that are used to calculate the CVI. It adds the ratings of three and four to an item and divides the result by the number of experts (Polit and Beck as quoted in Guo et al. 2019, 33; Shrotryia and Dhanda 2019,4). It is employed in this article as it is the preferred method for the purpose of ease of both calculation and getting the meaning of the results by showing the consensus or agreement among experts (Polit, Beck, and Owen 2007, 462). It also gives information at an item level and over the whole instrument (Zamanzadeh et al. $2015,169)$. The experts' responses in the last column of the instrument were considered qualitative findings and used in accordance with the experts' suggestions.

\section{Data Analysis, Findings and Discussions}

A content validity study generates both quantitative and qualitative data. Accordingly, in this article, the experts rated each item for its relevance, clarity, and representativeness, and evaluated the overall instrument quantitatively. They also gave useful comments on individual items and dimensions. Taking the qualitative data, the experts' comments resulted in changing the dimension that was originally called "Corporate Quality" to become "Corporate Image" as they indicated the smallness of the number of items in this dimension. They also commented that the dimension that was originally called "Communication" should not stand on its own as there is communication between students and academic supervisors, administrative support providers or academic facilitators in one form or another. Hence the items were agreed to be placed in the different dimensions that they were deemed to fall into. The experts suggested that the dimension that was originally called "Admin" be changed to "Administrative Support" as the former sounded informal (Aberra 2016, 110, 118). Table 3 shows the details of the experts' comments of the different items in the instrument. 
Table 3: Formulation of items based on experts' recommendations

\begin{tabular}{|c|c|}
\hline Item before expert check & Item after comments by experts \\
\hline $\begin{array}{l}\text { Supervisors should reflect an approachable } \\
\text { attitude when communicating with their } \\
\text { students }\end{array}$ & $\begin{array}{l}\text { Supervisors should be friendly/warm } \\
\text { when communicating with their } \\
\text { students }\end{array}$ \\
\hline $\begin{array}{l}\text { Supervisors should communicate with their } \\
\text { students via different technological media }\end{array}$ & $\begin{array}{l}\text { Supervisors should communicate with } \\
\text { their students via different } \\
\text { technological media such as email, } \\
\text { Skype, and chatting }\end{array}$ \\
\hline $\begin{array}{l}\text { Supervisors should encourage their students } \\
\text { to complete and submit draft chapters } \\
\text { regularly }\end{array}$ & $\begin{array}{l}\text { Supervisors should periodically } \\
\text { encourage their students to make the } \\
\text { required submissions such as chapters }\end{array}$ \\
\hline $\begin{array}{l}\text { Unisa should provide training to students on } \\
\text { the way in which to write a doctoral } \\
\text { proposal }\end{array}$ & $\begin{array}{l}\text { Unisa should provide training to } \\
\text { students on the way in which to } \\
\text { develop a doctoral proposal }\end{array}$ \\
\hline \multirow{2}{*}{$\begin{array}{l}\text { The Ethiopia Centre should ensure that its } \\
\text { library possesses a wide range of subject- } \\
\text { related and research books } \\
\text { (Item was found to have been double- } \\
\text { barrelled and split into two) }\end{array}$} & $\begin{array}{l}\text { The Ethiopia Centre should ensure } \\
\text { that its library possesses a wide range } \\
\text { of subject-related materials }\end{array}$ \\
\hline & $\begin{array}{l}\text { The Ethiopia Centre should ensure } \\
\text { that the library is equipped with recent } \\
\text { research books }\end{array}$ \\
\hline Newly added item & $\begin{array}{l}\text { Unisa should ensure that payment } \\
\text { made by self-sponsored students is } \\
\text { reflected on their accounts as quickly } \\
\text { as possible }\end{array}$ \\
\hline $\begin{array}{l}\text { Unisa should ensure that departmental } \\
\text { higher degrees committees communicate } \\
\text { with doctoral students on their decisions } \\
\text { regarding students' proposals in a } \\
\text { reasonable time }\end{array}$ & $\begin{array}{l}\text { Item placed under the dimension of } \\
\text { Administrative Support as the } \\
\text { dimension that was originally named } \\
\text { Communication was deleted }\end{array}$ \\
\hline $\begin{array}{l}\text { Unisa should provide information about } \\
\text { administrative procedures involving } \\
\text { doctoral students (eg intention to submit, } \\
\text { and library block) }\end{array}$ & Same as above \\
\hline \multirow[t]{2}{*}{$\begin{array}{l}\text { Supervisors and staff members of the } \\
\text { Ethiopia Centre should give information } \\
\text { concerning bursary applications and } \\
\text { research fund possibilities } \\
\text { (Item was found to be double-barrelled and } \\
\text { placed under "Communication" dimension) }\end{array}$} & $\begin{array}{l}\text { Supervisors should provide } \\
\text { information about research fund } \\
\text { possibilities } \\
\text { (Item was placed under the dimension } \\
\text { of Supervision Support) }\end{array}$ \\
\hline & $\begin{array}{l}\text { Unisa should ensure that the bursary } \\
\text { section provides timely responses } \\
\text { concerning bursary applications } \\
\text { (Item was placed under the dimension } \\
\text { of Administrative Support) }\end{array}$ \\
\hline
\end{tabular}




\begin{tabular}{|l|l|}
\hline Item before expert check & Item after comments by experts \\
\hline The Ethiopia Centre should have staff & The Ethiopia Centre should have staff \\
members who are freely available to & members who actively engage in \\
respond to students' enquiries & supporting doctoral students \\
(Item was place under "Communication" & (Item was rephrased and placed under \\
dimension) & the dimension of Academic \\
& Facilitation) \\
\hline
\end{tabular}

The process of content validity is iterative in reviewing literature, consulting with relevant persons, checking and rechecking items and dimensions by a sample of experts (Vogt, King, and King 2004, 236). Accordingly, in this study, six of the experts from the first pool (Kassam-Adams et al. 2015, 3) again checked the items for reconfirmation and found the distribution of the items that were originally placed under the dimension of Communication acceptable. They also rerated the split and the reformulated items, all of which resulted in having an I-CVI of 1.0. Table 4 shows the results of the experts' ratings.

Table 4: Results of the item-content validity index (I-CVI) by experts

\begin{tabular}{|c|c|c|c|c|c|}
\hline No & Items & $\begin{array}{l}\text { I-CVI for } \\
\text { relevance }\end{array}$ & $\begin{array}{l}\text { I-CVI } \\
\text { for } \\
\text { clarity }\end{array}$ & $\begin{array}{l}\text { I-FVI for } \\
\text { dimension }\end{array}$ & Remarks \\
\hline \multicolumn{6}{|c|}{ Items 1-11 were factored under the dimension of Supervision Support } \\
\hline 1 & $\begin{array}{l}\text { Clear comments from } \\
\text { supervisors }\end{array}$ & 1.0 & 1.0 & 1.0 & \\
\hline 2 & $\begin{array}{l}\text { Supervisors acknowledge receipt } \\
\text { of students' submissions }\end{array}$ & 1.0 & 1.0 & 1.0 & \\
\hline 3 & $\begin{array}{l}\text { Information on ethical clearance } \\
\text { procedures }\end{array}$ & 0.7 & 0.9 & 0.7 & \\
\hline 4 & $\begin{array}{l}\text { Friendly/warm communication } \\
\text { with students }\end{array}$ & 1.0 & $0.7(1.0)^{*}$ & 0.9 & $\begin{array}{l}\text { Rechecked for } \\
\text { clarity }\end{array}$ \\
\hline 5 & $\begin{array}{l}\text { Informing students of useful } \\
\text { resources }\end{array}$ & 1.0 & 1.0 & 1.0 & \\
\hline 6 & $\begin{array}{l}\text { Using different technological } \\
\text { media for communication }\end{array}$ & 1.0 & $0.7(1.0)$ & 1.0 & $\begin{array}{l}\text { Rechecked for } \\
\text { clarity }\end{array}$ \\
\hline 7 & $\begin{array}{l}\text { Guidance on governing rules } \\
\text { and policies }\end{array}$ & 0.7 & 1.0 & 0.8 & \\
\hline 8 & $\begin{array}{l}\text { Supervisors' timely responses to } \\
\text { students' submissions }\end{array}$ & 1.0 & 1.0 & 1.0 & \\
\hline 9 & $\begin{array}{l}\text { Supervisors' periodically } \\
\text { encouraging their students }\end{array}$ & 1.0 & $0.78(1.0)$ & 0.89 & $\begin{array}{l}\text { This item was } \\
\text { not rated by } \\
\text { one expert. It } \\
\text { was rechecked } \\
\text { for clarity }\end{array}$ \\
\hline 10 & $\begin{array}{l}\text { Comments of supervisors being } \\
\text { fairly consistent over time }\end{array}$ & 0.9 & 1.0 & 1.0 & \\
\hline 11 & $\begin{array}{l}\text { Provision of information on } \\
\text { research fund possibilities }\end{array}$ & 1.0 & 1.0 & 1.0 & $\begin{array}{l}\text { Reframed by } \\
\text { the experts }\end{array}$ \\
\hline
\end{tabular}




\begin{tabular}{|c|c|c|c|c|c|}
\hline No & Items & $\begin{array}{l}\text { I-CVI for } \\
\text { relevance }\end{array}$ & $\begin{array}{l}\text { I-CVI } \\
\text { for } \\
\text { clarity }\end{array}$ & $\begin{array}{l}\text { I-FVI for } \\
\text { dimension }\end{array}$ & Remarks \\
\hline \multicolumn{4}{|c|}{ CVI for Dimensionality } & 0.94 & \\
\hline \multicolumn{6}{|c|}{ Items $12-24$ were factored under the dimension of Infrastructure } \\
\hline 12 & $\begin{array}{l}\text { E-book and e-journal collections } \\
\text { in the library }\end{array}$ & 0.9 & 1.0 & 1.0 & \\
\hline 13 & $\begin{array}{l}\text { myUnisa to curb students' } \\
\text { loneliness }\end{array}$ & 1.0 & 0.9 & 0.9 & \\
\hline 14 & $\begin{array}{l}\text { Library accessible after working } \\
\text { hours }\end{array}$ & 0.9 & 0.9 & 1.0 & \\
\hline 15 & $\begin{array}{l}\text { Online library accessible } \\
\text { throughout the year }\end{array}$ & 1.0 & 1.0 & 1.0 & \\
\hline 16 & $\begin{array}{l}\text { Accessibility of venues for } \\
\text { workshops, seminars and } \\
\text { training }\end{array}$ & 0.9 & 1.0 & 1.0 & \\
\hline 17 & $\begin{array}{l}\text { Up-to-date ICT resources in labs } \\
\text { and library }\end{array}$ & 1.0 & 0.9 & 1.0 & \\
\hline 18 & $\begin{array}{l}\text { User-friendliness of the } \\
\text { myUnisa system }\end{array}$ & 1.0 & 1.0 & 1.0 & \\
\hline 19 & $\begin{array}{l}\text { User-friendliness of the myLife } \\
\text { email }\end{array}$ & 1.0 & 1.0 & 1.0 & \\
\hline 20 & $\begin{array}{l}\text { Assistance for ICT-related } \\
\text { challenges }\end{array}$ & 1.0 & 1.0 & 1.0 & \\
\hline 21 & $\begin{array}{l}\text { Library possess subject-related } \\
\text { materials }\end{array}$ & 0.9 & 0.9 & 1.0 & $\begin{array}{l}\text { Split based on } \\
\text { comments by }\end{array}$ \\
\hline 22 & $\begin{array}{l}\text { Library equipped with recent } \\
\text { research books }\end{array}$ & 1.0 & 1.0 & 1.0 & experts \\
\hline 23 & Accessibility of computer labs & 0.9 & 1.0 & 1.0 & \\
\hline 24 & Accessibility of Ethiopia Centre & 0.9 & 0.9 & 1.0 & \\
\hline \multirow{2}{*}{\multicolumn{4}{|c|}{ CVI for Dimensionality }} & 0.99 & \\
\hline & \multicolumn{5}{|c|}{ Items $25-32$ were factored under the dimension of Administrative Support } \\
\hline 25 & $\begin{array}{l}\text { Information on admission } \\
\text { requirements }\end{array}$ & 1.0 & 0.9 & 0.9 & \\
\hline 26 & $\begin{array}{l}\text { Provision of information on } \\
\text { doctoral applications }\end{array}$ & 0.9 & 1.0 & 0.89 & $\begin{array}{l}\text { This item was } \\
\text { not rated by } \\
\text { one expert for } \\
\text { dimension }\end{array}$ \\
\hline 27 & $\begin{array}{l}\text { Responses on admission } \\
\text { decisions }\end{array}$ & 1.0 & 0.9 & 0.89 & $\begin{array}{l}\text { This item was } \\
\text { not rated by } \\
\text { one expert for } \\
\text { dimension }\end{array}$ \\
\hline 28 & $\begin{array}{l}\text { User-friendliness of registration } \\
\text { and re-registration }\end{array}$ & 1.0 & 0.9 & 1.0 & \\
\hline 29 & $\begin{array}{l}\text { Timely finalisation of students' } \\
\text { payment processes }\end{array}$ & 0.9 & 0.9 & 1.0 & $\begin{array}{l}\text { Was omitted } \\
\text { and added by } \\
\text { the experts }\end{array}$ \\
\hline 30 & $\begin{array}{l}\text { Communicating decisions on } \\
\text { proposals }\end{array}$ & 1.0 & 0.9 & 1.0 & $\begin{array}{l}\text { Imported from } \\
\text { Communication }\end{array}$ \\
\hline 31 & $\begin{array}{l}\text { Provision of information on } \\
\text { administrative procedures }\end{array}$ & 1.0 & 1.0 & 1.0 & \\
\hline 32 & $\begin{array}{l}\text { Information of bursary and } \\
\text { research fund possibilities }\end{array}$ & 0.9 & 1.0 & 1.0 & \\
\hline \multicolumn{4}{|c|}{ CVI for Dimensionality } & 0.96 & \\
\hline
\end{tabular}




\begin{tabular}{|c|c|c|c|c|c|}
\hline No & Items & $\begin{array}{l}\text { I-CVI for } \\
\text { relevance }\end{array}$ & $\begin{array}{l}\text { I-CVI } \\
\text { for } \\
\text { clarity }\end{array}$ & $\begin{array}{l}\text { I-FVI for } \\
\text { dimension }\end{array}$ & Remarks \\
\hline \multicolumn{6}{|c|}{ Items 33-36 were factored under the dimension of Corporate Image } \\
\hline 33 & $\begin{array}{l}\text { Unisa is a leading research } \\
\text { university internationally }\end{array}$ & 1.0 & 0.9 & 1.0 & \\
\hline 34 & $\begin{array}{l}\text { Alumni of Unisa have a high } \\
\text { status in Ethiopia }\end{array}$ & 1.0 & 1.0 & 1.0 & \\
\hline 35 & $\begin{array}{l}\text { Unisa grants doctoral degrees } \\
\text { that are of an international } \\
\text { standard }\end{array}$ & 1.0 & 1.0 & 1.0 & \\
\hline 36 & $\begin{array}{l}\text { Ethiopians that have graduated } \\
\text { from Unisa are proud of their } \\
\text { qualifications }\end{array}$ & 0.9 & 1.0 & 0.9 & \\
\hline \multirow{2}{*}{\multicolumn{6}{|c|}{\begin{tabular}{l|c} 
CVI for Dimensionality & 0.98 \\
Items $37-50$ were factored under the dimension of Academic Facilitation
\end{tabular}}} \\
\hline & & & & & \\
\hline 37 & $\begin{array}{l}\text { Orientation of newly admitted } \\
\text { students to acquaint them with } \\
\text { ODeL }\end{array}$ & 1.0 & 1.0 & 1.0 & \\
\hline 38 & $\begin{array}{l}\text { Provision of orientation early in } \\
\text { the new academic year }\end{array}$ & 1.0 & $0.78(1.0)$ & 1.0 & $\begin{array}{l}\text { This item was } \\
\text { not rated by } \\
\text { one expert. It } \\
\text { was rechecked } \\
\text { for clarity }\end{array}$ \\
\hline 39 & $\begin{array}{l}\text { Assignment of mentors for } \\
\text { students who have local } \\
\text { supervisors }\end{array}$ & 1.0 & 1.0 & 1.0 & \\
\hline 40 & $\begin{array}{l}\text { Assignment of supervisors or } \\
\text { contact persons upon registration }\end{array}$ & 1.0 & 0.9 & 1.0 & \\
\hline 41 & $\begin{array}{l}\text { Training on the way in which to } \\
\text { develop doctoral proposals }\end{array}$ & 1.0 & 1.0 & 1.0 & \\
\hline 42 & $\begin{array}{l}\text { Ethiopia Centre staff members } \\
\text { supporting students }\end{array}$ & 0.8 & 0.8 & 0.89 & $\begin{array}{l}\text { This item was } \\
\text { not rated by } \\
\text { one expert for } \\
\text { dimension }\end{array}$ \\
\hline 43 & $\begin{array}{l}\text { Training on accessing online } \\
\text { library resources }\end{array}$ & 0.9 & 0.8 & 0.89 & $\begin{array}{l}\text { This item was } \\
\text { not rated by } \\
\text { one expert for } \\
\text { dimension }\end{array}$ \\
\hline 44 & $\begin{array}{l}\text { Delivery of books received from } \\
\text { South Africa }\end{array}$ & 0.89 & 1.0 & 0.88 & $\begin{array}{l}\text { This item was } \\
\text { not rated by } \\
\text { one expert for } \\
\text { relevance and } \\
\text { clarity and by } \\
\text { two experts for } \\
\text { dimension }\end{array}$ \\
\hline 45 & Assignment of subject librarians & 1.0 & 1.0 & 1.0 & \\
\hline 46 & $\begin{array}{l}\text { Relevance of training to } \\
\text { students' research }\end{array}$ & 1.0 & 0.8 & 0.88 & $\begin{array}{l}\text { This item was } \\
\text { not rated by } \\
\text { two experts for } \\
\text { dimension }\end{array}$ \\
\hline 47 & $\begin{array}{l}\text { Supervisors and students signing } \\
\text { agreement }\end{array}$ & 1.0 & 1.0 & 1.0 & \\
\hline 48 & Training on data analysis & 1.0 & 1.0 & 1.0 & \\
\hline
\end{tabular}




\begin{tabular}{|c|l|l|l|l|l|}
\hline No & Items & $\begin{array}{l}\text { I-CVI for } \\
\text { relevance }\end{array}$ & $\begin{array}{l}\text { I-CVI } \\
\text { for } \\
\text { clarity }\end{array}$ & $\begin{array}{l}\text { I-FVI for } \\
\text { dimension }\end{array}$ & Remarks \\
\hline 49 & $\begin{array}{l}\text { Poftware } \\
\text { post-proposal students }\end{array}$ & 1.0 & 1.0 & 1.0 & \\
\hline 50 & $\begin{array}{l}\text { Active engagement of Ethiopia } \\
\text { Centre staff members in } \\
\text { supporting doctoral students }\end{array}$ & 1.0 & 1.0 & 1.0 & $\begin{array}{l}\text { Imported from } \\
\text { Communication } \\
\text { Reframed by } \\
\text { the experts }\end{array}$ \\
\hline CVI for Dimensionality & & & 0.97 & \\
\hline$S$-CVI
\end{tabular}

*Numbers in brackets are the results after rerating

Table 4 shows that items 3 and 7 have earned an I-CVI of 0.7 for relevance. These two items were kept in the instrument in accordance with the advice of Zamanzadeh et al. $(2015,169)$ who said that ratings between 0.7 and 0.79 should be kept for further revision. The content validity for the overall instrument (S-CVI) was calculated by two methods. The first method is the S-CVI/Ave, which adds all the values of the ratings for each item divided by the number of items. In this study, the S-CVI for relevance and clarity of the overall instrument is 0.96 each. Similarly, the S-CVI/Ave for each dimension was calculated and it was 0.94 for the dimension of Supervision Support, 0.99 for Infrastructure, 0.96 for Administrative Support, 0.98 for Corporate Image, and 0.97 for Academic Facilitation. All these results are acceptable as they are above 0.90 (Polit, Beck, and Owen 2007, 491-93).

The second method of calculating the S-CVI is to ask experts to rate the comprehensiveness of the instrument (Aberra 2016, 115). The experts were asked to answer an item that reads "Overall, the items included in this instrument representatively measure the construct of student support service quality in an OpenDistance e-Learning environment". They were given the scale of $1=$ Not representative, 2 Somewhat representative, $3=$ Quite representative, and $4=$ Highly representative. Although only four experts responded to this item, the result S-CVI $=1.0$, showing that the overall instrument is comprehensive to measure the quality of student support services in ODeL.

Table 5 shows the names of the dimensions, the contextual meaning of each of the dimensions and the number of items that fall in each dimension after the content validity procedure is finalised.

Table 5: Dimensions, contextual definitions and number of items

\begin{tabular}{|l|l|l|l|}
\hline $\begin{array}{l}\text { N } \\
\mathbf{o}\end{array}$ & Name of dimension & Contextual definitions & $\begin{array}{l}\text { Number of } \\
\text { items/dimension (after } \\
\text { rerating) }\end{array}$ \\
\hline 1 & Supervision support & $\begin{array}{l}\text { Issues that are directly linked to } \\
\text { the academic activities of the }\end{array}$ & 11 \\
\hline
\end{tabular}




\begin{tabular}{|c|c|c|c|}
\hline $\begin{array}{l}\mathbf{N} \\
\mathbf{0}\end{array}$ & Name of dimension & Contextual definitions & $\begin{array}{l}\text { Number of } \\
\text { items/dimension (after } \\
\text { rerating) }\end{array}$ \\
\hline & & $\begin{array}{l}\text { students in relation to the } \\
\text { instructions or guidance rendered } \\
\text { by supervisors }\end{array}$ & \\
\hline 2 & Administrative support & $\begin{array}{l}\text { Communicating decisions by } \\
\text { different-level officials of the } \\
\text { university and also services that } \\
\text { are related to application and } \\
\text { registration processes }\end{array}$ & 8 \\
\hline 3 & Infrastructure & $\begin{array}{l}\text { Resources related to both physical } \\
\text { and non-physical (soft format) set- } \\
\text { ups that the university provides }\end{array}$ & 13 \\
\hline 4 & Academic facilitation & $\begin{array}{l}\text { Activities that the university } \\
\text { provides to ease and assist the } \\
\text { academic journey of doctoral } \\
\text { students and that also have the } \\
\text { intention of increasing throughput } \\
\text { (retention and graduation) }\end{array}$ & 14 \\
\hline 5 & Corporate image & $\begin{array}{l}\text { Issues related to the status or } \\
\text { reputation of the university in the } \\
\text { eyes of different stakeholders }\end{array}$ & 4 \\
\hline \multicolumn{3}{|c|}{ TOTAL } & 50 \\
\hline
\end{tabular}

\section{Conclusion and Recommendations}

This study clearly shows the importance and usefulness of content validity in the process of developing a valid instrument. The procedures followed helped to gather comments for refining the items and their respective dimensions in terms of reformulation, splitting of double-barrelled items, and adding omitted items. In terms of the quantitative findings, items' clarity in being understandable to the target group of doctoral students, their relevance in measuring the quality of student support services, and the dimensionality in specifying each item to its respective dimension were all secured. The overall comprehensiveness of the instrument has also been achieved. It is recommended that content validity be undertaken for the sake of making an instrument for the appropriate items and content domains. Procedures such as running Cronbach's alpha and factor analysis also help to secure construct validity for further refinement of an instrument.

\section{References}

Aberra, T. G. M. 2016. "Ensuring the Quality of Doctoral Student Support Services in Open Distance Learning." $\mathrm{PhD}$ thesis, University of South Africa. http://hdl.handle.net/10500/22138. 
Dzakiria, H. 2005. “The Role of Learning Support in Open and Distance Learning: Learners' Experiences and Perspectives.” Turkish Online Journal of Distance Education 6 (2): 95109.

Field, A. 2009. Discovering Statistics Using SPSS. London: Sage.

Grant, J. S., and L. L. Davis. 1997. "Focus on Quantitative Methods Selection and Use of Content Experts for Instrument Development." Research in Nursing and Health 20 (3): 269-74. https://doi.org/10.1002/(SICI)1098-240X(199706)20:3\%3C269::AIDNUR9\%3E3.0.CO;2-G.

Guo, L., M. C. Jones, Y. Liu, S. Yv, Y. Zhu, and Y. Guo. 2019. "Cross-Cultural Validation of the Student Nurse Stress Index Scale: A Descriptive Survey Targeting Student Nurses in China." Journal of Affective Disorders 251: 31-39. https://doi.org/10.1016/j.jad.2019.03.017.

Jain, R., G. Sinha, and S. K. De. 2010. "Service Quality in Higher Education: An Exploratory Study." Asian Journal of Marketing 4 (3): 144-54.

Jung, I., T. M. Wong, C. Li, S. Baigaltugs, and T. Belawati. 2011. "Quality Assurance in Asian Distance Education: Diverse Approaches and Common Culture." International Review of Research in Open and Distance Learning 12 (6): 63-83. https://doi.org/10.19173/irrodl.v12i6.991.

Kassam-Adams, N., M. L. Marsac, K. L. Kohser, J. A. Kenardy, S. March, K. Flaura, and F. K. Winston. 2015. “A New Method for Assessing Content Validity in Model-Based Creation and Iteration of eHealth Interventions." Journal of Medical Internet Research 17 (4): 1-8. https://doi.org/10.2196/jmir.3811.

Lampley, J. H. 2001. "Service Quality in Higher Education: Expectations versus Experiences of Doctoral Students." Journal of the American Association of Collegiate Registrars and Admissions Officers 77 (2): 9-14.

Magasi, S., G. Ryan, D. Revicki, W. Lenderking, R. D. Hays, M. Brod, C. Snyder, M. Boers, and D. Cella. 2012. "Content Validity of Patient-Reported Outcome Measures: Perspectives from a PROMIS Meeting." Qualitative Life Research 2 (1): 739-46. https://doi.org/10.1007/s11136-011-9990-8.

Maguad, B. A., and R. M. Krone. 2012. "Managing for Quality in Higher Education: A Systems Perspective."

http://www.globaleduc8tions.org/images/Management_Ebooks/ManagingqualityinHE.pdf.

Malhotra, N. K., F. M. Ulgado, J. Agarwal, G. Shainesh, and L. Wu. 2005. "Dimensions of Service Quality in Developed and Developing Economies: Multi-Country Cross-Cultural Comparisons." International Marketing Review 22 (3): 256-78. 
Newman, I., J. Lim, and F. Pineda. 2013. “Content Validity using a Mixed Methods Approach: Its Application and Development through the Use of a Table of Specifications Methodology." Journal of Mixed Methods Research 7 (3): 243-260. https://doi.org/10.1177/1558689813476922.

Polit, D. F., C. T. Beck, and S. V. Owen. 2007. "Is the CVI an Acceptable Indicator of Content Validity? Appraisal and Recommendations." Research in Nursing and Health 30: 459-67. https://doi.org/10.1002/nur.20199.

Rubio, D. M., M. Berg-Weger, S. S. Tebb, E. S. Lee, and S. Rauch. 2003. “Objectifying Content Validity: Conducting a Content Validity Study in Social Work Research." Social Work Research 27 (2): 94-104. https://doi.org/10.1093/swr/27.2.94.

Shrotryia, V. K., and U. Dhanda. 2019. "Content Validity of Assessment Instrument for Employee Engagement.” Sage Open 1-7. https://doi.org/10.1177/2158244018821751.

Southard, S., and M. Mooney. 2015. "A Comparative Analysis of Distance Education Quality Assurance Standards.” Quarterly Review of Distance Education 16 (1): 55-68.

Sultan, P., and H. Y. Wong. 2010. "Service Quality in Higher Education - A Review and Research Agenda.” International Journal of Quality and Service Sciences 2 (2): 259-72.

Tait, A. 2014. "From Place to Virtual Space: Reconfiguring Student Support for Distance and E-Learning in the Digital Age." Open Praxis 6 (1): 5-16. https://doi.org/10.5944/openpraxis.6.1.102.

Teeroovengadum, V., T. J. Kamalanabhan, and A. K. Seebaluck. 2016. "Measuring Service Quality in Higher Education." Quality Assurance in Education 24 (2): 244-58. https://doi.org/10.1108/QAE-06-2014-0028.

Vogt, D. S., D. W. King, and L. A. King. 2004. "Focus Groups in Psychological Assessment: Enhancing Content Validity by Consulting Members of the Target Population." Psychological Assessment 16 (3): 231-43. https://doi.org/10.1037/1040-3590.16.3.231.

Witte, N. D., S. Labeau, W. D. Keyzer. 2011. "The Clinical Learning Environment and Supervision Instrument (CLES): Validity and Reliability of the Dutch Version (CLES + NL)." International Journal of Nursing Studies 48: 568-72. https://doi.org/10.1016/j.ijnurstu.2010.09.009.

Zamanzadeh, V., A. Ghahramanian, M. Rassouli, A. Abbaszadeh, H. AlaviMajd, and AR. Nikanfar. 2015. "Design and Implementation Content Validity Study: Development of an Instrument for Measuring Patient-Centred Communication." Journal of Caring Sciences 4 (2): 165-178. https://doi.org/10.15171/jcs.2015.017. 